\title{
NARRADOR E POETA EM FAGUNDES VARELA: ANCHIETA OU O EVANGELHO NAS SELVAS (1875)
}

\author{
NARRATOR AND POET IN FAGUNDES VARELA: \\ ANCHIETA OU O EVANGELHO NAS SELVAS (1875)
}

Roger Friedlein ${ }^{1}$

\begin{abstract}
Resumo: No poema de dimensões épicas Anchieta ou o Evangelho nas selvas (1875), Fagundes Varela encena José de Anchieta na missão, relatando o Evangelho aos índios em Piratininga. $\mathrm{O}$ artigo analisa as ideias sobre poesia e o poeta, portanto autorreflexivas, transmitidas nessa configuração. Diferenciando nítidamente a poetologia da figura do narrador intradiegético da voz poética do Eu, Varela se distancia da autorreflexividade historicista do Romantismo anterior para chegar a uma poética individualista.
\end{abstract}

Palavras chave: Fagundes Varela, José de Anchieta, autorreflexividade, poesia épica, Romantismo.

\begin{abstract}
In his poem of epic dimensions Anchieta ou o Evangelho nas selvas (1875), Fagundes Varela stages the Brazilian missionary José de Anchieta telling the Gospel to his indigenous public. The article analizes the self-referential ideas about poetry and poets that are transmitted in the poem. The characteristics of the intradiegetic narrator Anchieta differ clearly from those of the poetical narrator in first person. Varela takes thus his distances from the historicist self-referentiality of former Romanticism and makes way towards a more individualist poetics.
\end{abstract}

Keywords: Fagundes Varela, José de Anchieta, meta-reference, epic poetry, Romanticism

Anchieta ou o Evangelho nas selvas (edição póstuma de 1875$),{ }^{2}$ de Luís Nicolau Fagundes Varela (Rio Claro, RJ, 1841-1875), ${ }^{3}$ é um texto largamente ignorado e com má fortuna crítica, embora represente um ambicioso projeto de poetizar o encontro dos originais moradores do território brasileiro com a missão cristã e, ao mesmo tempo, relatar o texto evangélico numa tentativa de poema religioso de dimensões épicas. Surgiu num contexto cronológico em que a poesia épica já se encontrava numa fase avançada de transformação, induzida pelo Romantismo. O poema foi reimpresso várias vezes, sobretudo dentro da obra completa de Varela, que é, excetuando-se o poema narrativo em questão e algumas narrativas em prosa, quase exclusivamente lírica. ${ }^{4}$ Focado na figura de José de Anchieta, o poema

\footnotetext{
${ }^{1}$ Ruhr-Universität Bochum - RUB, Bochum, Alemanha; https://orcid.org/0000-0001-8844-1721; roger.friedlein@rub.de

${ }^{2}$ Usaremos a primeira edição, publicada logo após o falecimento do poeta em 1875. Além das reedições dentro de obras completas do poeta existe uma edição popular fluminense de 1939 (1957), prefaciada pelo poeta Murilo Araújo (Fagundes Varela, 1939).

${ }^{3}$ A biografia de Fagundes Varela teve um primeiro contributo na forma de resenha biográfica, traduzida do Anglo-Brazilian Times para republicação na primeira edição de Anchieta. V. as biografias mais recentes de Barros (1965), Azevedo (1966) e a nota seguinte.

${ }^{4}$ A Academia de Letras publicou uma biobibliografia do seu patrono de poltrona (Lima, 2003).
} 
desenvolve para uma direção específica o potencial épico que tempos atrás já tinha sido percebido na figura de Anchieta, por exemplo, por José de Alencar, como ressalta Maria Aparecida Ribeiro no seu abrangente trabalho sobre as figurações literárias do padre missionário (Ribeiro, 2003, p. 28-29). O poema de Fagundes Varela retrata os primeiros tempos da missão de Piratininga, ${ }^{5}$ núcleo rural embrionário da sociedade colonial, atingido, inclusive desde a distância geográfica, pelo conflito bélico que envolvia as comunidades índias, os portugueses e franceses na região fluminense. Porém - e neste aspecto Anchieta difere do poema épico mais representativo do seu tempo, A Confederação dos Tamoios, de Gonçalves Magalhães -, o poema de Fagundes Varela não tem pretensões de virar uma epopeia identitária para a jovem nação brasileira, na esteira da Eneida ou d'Os Lusíadas. Bem mais pertence à tradição da epopeia sacra, da qual cita explicitamente os nomes de Dante e Milton, assim como Thomas de Kempis, o autor da Imitatio Christi. ${ }^{6}$ Anchieta, mesmo sendo um poema épico formalmente já bastante transformado quando comparado às tradições secular e religiosa que conformam as duas linhas do gênero, estabelece porém claras intertextualidades nesse sentido e, para uma leitura adequada, há-de ser visto dentro dessa mesma tradição. Antes de voltarmonos à questão do seu teor autorreflexivo, tema específico deste artigo, convém assinalar as duas intertextualidades épicas mais salientes do poema.

Os chamados 'poemas narrativos' a partir do Romantismo em muitos sentidos continuam e desenvolvem a tradição épica, mas costumam suprimir o marcador de gênero mais evidente, quando abdicam do uso de proêmios épicos. Na sua forma mais clássica, esses eram constituídos pelos elementos proposição, invocação e dedicação. O poema narrativo, porém, costuma arrancar na diegese narrativa, sem preliminares.

Em Anchieta, as dez partes do poema são denominadas de canto e divididas em estâncias decassilábicas com rima branca, de número e cumprimento irregular e desigual. As três primeiras de 42 estâncias do primeiro canto constam de 58, 50 e 13 versos respetivamente, e retomam manifestamente a forma e função introdutória do proêmio épico, até a diegese começar na estância quarta. Não falto de originalidade, Varela dedica as primeiras duas estâncias a duas invocações complementárias das árvores alegóricas da Bíblia. A primeira, negativa no caso, é dirigida à execrada "Árvore da Ciência", abominada pelas exclamações da voz poética. No entanto, ao pé da segunda, a "Árvore da Cruz", a voz poética se propõe celebrar milagres, doutrinas e martírios de Jesus Christo, evocando ao mesmo tempo as suas lembranças de infância com o relato das "maravilhas que aprendeu, creança, / Dos santos labios de ministro santo, / Nas amplas solidões do Novo Mundo!" (I, 2). ${ }^{7}$

A estância concluinte desse proêmio, a terceira e mais breve, invoca a "Celeste Musa! Socia immaculada / Dos prophetas hebreus!” (I, 3), e coloca do lado da poesia bíblica os já mencionados três autores de poesia religiosa, Dante, Milton e Thomas a Kempis. ${ }^{8}$ São apresentados como quem é capaz de governar o vôo do Eu para além das esferas, dando,

\footnotetext{
${ }^{5}$ Mencionada explícitamente no poema, canto I, est. 4. Cantos e estâncias vão ambos numerados com algarismos romanos na primeira edição.

6 “Oh! de Milton e Dante augustas sombras! / Genio de Kempis!... governai meu estro!” (I, 3). Depois, Gonçalves Dias é o único nome nacional mencionado, não como poeta sacro, mas como modelo estilístico (I, 10). - Thomas a Kempis (ca. 1380-1471) era originário da cidade de Kempen, na Baixa Renânia, e foi autor da Imitatio Christi, exemplo mais representativo da devotio moderna e, com aproximadamente mil edições em latim e várias línguas vernáculas, é tido como o livro cristão mais impresso depois da Bíblia. Escrito em versos latinos e dividido em quatro partes, não possui caráter narrativo e consiste em pensamentos e avisos de devoção cristã.

${ }^{7}$ Neste caso não será fora de lugar de lembrar que Fagundes Varela, nascido no Rio de Janeiro, teve uma primeira infância no município de Catalão, na então afastadíssima província de Goiás, onde seu pai exercia um cargo na função pública.

${ }^{8} \mathrm{Na}$ biblioteca do jovem Varela estudante, felizmente documentada, consta a existência da Divina Comedia de Dante, entre uma quarentena de livros predominantemente franceses e sem exemplos de literatura brasileira ou portuguesa (Haberly, 1987).
} 
portanto, um cariz místico ao poema. Se nos modelos citados, sobretudo em Dante, a viagem do Eu poético não fica alheia à aquisição de conhecimento ao longo dela, em Anchieta o Eu apresenta seu poema, opondo-o a qualquer encenação de saberes. Este tipo de encenações caraterizava não só a visão do mais-além na Divina Comedia, mas virou, na sua variante mundana, quase um sinal de marca de toda a linha secular da epopeia desde Os Lusíadas. No poema camoniano, como em tantas epopeias mais, concretam-se num tipo de episódio cosmográfico que pode ser chamado de cosmovisão épica (Friedlein, 2015). Enquanto n'Os Lusíadas a visão da máquina do mundo por Vasco da Gama forma o momento culminante do poema, Fagundes Varela retoma essa tradição motívica para conferir-lhe um valor totalmente oposto. Depois do proêmio, esta será a segunda intertextualidade do poema com a tradição épica. A cosmovisão em Anchieta encontra-se no segundo canto, em que se relata a tentação de Jesus no deserto. Conforme o poema, o demônio disfarça sua tentativa de sedução do jovem Jesus para os seus fins malévolos, mostrando-lhe numa cosmovisão maravilhosa as partes geográficas do mundo, começando pela Ásia, passando pela Europa e África, e chegando à Terra Prometida: as Américas. Jesus Cristo é levado a essa cosmovisão pelo diabo num vôo panorâmico por cima dos continentes, com a finalidade de ostentar a riqueza do mundo material que Jesus, uma vez súbdito ao demônio, poderia dominar. Como é sabido e se confirma em Anchieta, Jesus resiste à tentação do mundo e faz com que o demônio aterrise em Jerusalém. O motivo da cosmovisão épica que na Ilha dos Amores camoniana significava o cúmulo da peripécia dos marinheiros e o atingimento do saber, é portanto retomado e invalidado por Fagundes Varela, para deixar manifesto o viés anticientífico do seu poema e situá-lo ao mesmo tempo longe da tradição da epopeia secular e das suas encenações de saberes.

De qualquer modo, tanto o proêmio, como a cosmovisão em Anchieta demonstram como os poemas (pós-)épicos do século XIX em muitos casos podem não se afirmar como tais, mas só serão adequadamente entendidos quando vistos desde a tradição a que se referenciam. Não somente os dois trechos analisados até agora demonstram a pertinência épica de Anchieta, mas ao mesmo tempo já constituem exemplos de autorreflexividade literária, em tanto que transmitem e formulam ideias sobre o que há de ser a poesia.

\section{A Confederação dos Tamoios, ponto de comparação}

Para ressaltar as características da autorreflexão em Fagundes Varela, A Confederação dos Tamoios (1856), de Gonçalves de Magalhães, pode servir como pano de fundo. Presta-se especialmente para esse fim, não só sendo o texto épico brasileiro paradigmático da época, mas sobretudo porque os dois poemas compartilham na figura do padre José de Anchieta um mesmo protagonista, encenado de maneira significativamente diferente. A partir do tratamento diferenciado que Anchieta recebe nos dois poemas, podem-se definir duas maneiras de conceber a função da poesia épica e a tarefa do poeta, quer dizer duas poetologias, para usar um termo habitual na teoria literária alemã com o fim de diferenciar as teorias inerentes às obras literárias daquelas formuladas nas poéticas, e portanto fora do texto literário.

A Confederação dos Tamoios relata, como é sabido, os acontecimentos relacionados à revolta de uma coligação de tribos índias sob a liderança do chefe Jaguanharo, dirigida contra os colonos portugueses, no contexto do conflito entre colonizadores portugueses e franceses na região da Baía de Guanabara. Os portugueses agem nesse conflito com tropas lideradas por Estácio de Sá, logo apoiado pelo seu tio Mem de Sá, e estão por sua vez coaligados com outras comunidades indígenas. A batalha decisiva leva não só à destruição do forte francês de Coligny, mas à derrota dos tamoios e à fundação da cidade do Rio de Janeiro. Junto com Mem de Sá, o José de Anchieta histórico estava presente e envolvido nesses acontecimentos, e hoje sabe-se que foi autor de um poema épico em latim que os relata: De gestis Mendi de Saa (1563), primeiro poema épico da América do Sul. No entanto, a epopeia de Anchieta em língua latina, 
apesar de existir uma edição coimbrã do séc. XVI e ser mencionada na biografia anchietana de Simão de Vasconcelos, ${ }^{9}$ não foi redescoberta e conhecida até o século XX. ${ }^{10}$ Essa autoria de Anchieta poderia ter dado ocasião para intertextualidades nos poemas épicos do século XIX que fossem tratar o tema do missionário, mas não foi o caso, porque tanto Gonçalves de Magalhães quanto Fagundes Varela ignoravam a faceta épica do padre. Para eles como para toda a história literária do século XIX, Anchieta era o autor de poemas líricos em português, espanhol e tupi, de peças teatrais, de cartas e relatórios em prosa e de um extenso poema mariano em latim, Carmen de Beata Virgine Matre Dei Maria, ou Poema marianum. Essa última composição poderia ser considerada candidata à epopeia sacra, ${ }^{11}$ mas, mesmo assim, propicia muito menos do que De gestis Mendi de Saa, claramente épico, a estilização de Anchieta como poeta épico.

Apesar do desconhecimento da epopeia anchietana, Gonçalves de Magalhães emprende a missão poetológica de fazer aparecer o religioso nA Confederação dos Tamoios não só como missionário e negociador político, mas sobretudo como figura fundacional da poesia brasileira, e ainda na faceta épica dessa. ${ }^{12}$ Apresenta Anchieta como quem estendeu uma ponte entre a tradição literária oral autóctone, intimamente ligada à natureza brasileira, e a tradição literária cristã, aportada por ele. Anchieta, $\mathrm{n}$ A Confederação dos Tamoios, aparece como um poeta com claros traços românticos, inspirado pelo Deus cristão tanto quanto pela natureza brasileira, e em intercâmbio e troca artística com os representantes da poesia indígena autóctone. A partir de Anchieta como figura fundacional, A Confederação dos Tamoios menciona uma fileira de poetas brasileiros, preferentemente com obra épica, que desemboca nas duas figuras de poetas contemporâneos, épicos e nacionais: Manuel de Araújo Porto-Alegre e o próprio Gonçalves de Magalhães. Essa prolepse autorreflexiva é possível dentro do próprio poema através de uma visão profética do futuro poético do Brasil, realizada numa digressão do narrador. ${ }^{13}$ Desde o ponto de vista autorreflexivo, o essencial da Confederação é o fato de o poema atribuir a ele próprio a função de continuar e atualizar uma tradição poética nacional. Constrói uma fileira histórica épica que forma o contributo dos poetas à construção da nação como entidade histórica. Foi um objetivo aliás compartilhado por ambos os lados da polêmica sobre a A Confederação dos Tamoios, armada entre os partidários de Gonçalves de Magalhães por um lado e os de José de Alencar por outro. No nosso contexto importa, porém, a posição fundacional que a Confederação atribui a Anchieta na construção histórica de uma tradição épica nacional: é na figura dele que se reúnem por primeira vez a arte natural dos habitantes do país com a arte cristã dos recém-chegados, e o narrador de A Confederação dos Tamoios, mesmo sem conhecimento do De gestis Mendi de Saa, aspira a ocupar um lugar na tradição consecutiva.

\section{Anchieta ou o Evangelho nas selvas: conteúdo e narratologia}

Diante do pano de fundo do indianismo na poesia épica, a autorreflexividade de Anchieta ou o Evangelho nas selvas desenvolve-se de maneira diferenciada. Para entender as

\footnotetext{
${ }^{9}$ A edição coimbrã (Conimbricae: apud Ioannem Aluarum Typographum Regium, 1563) não leva nome de autor. Existe em versão fac-similada da Biblioteca Nacional de Rio de Janeiro (Anchieta, 1997).

${ }^{10}$ O poema despertou certo interesse na recente crítica alemã; além de Lestringant (1996), v. os estudos de Briesemeister (2002), Jaeckel (2007) e Arias-Schreiber Barba (2011), ao lado das edições bilíngues de Armando Cardoso (lat.-pt., Anchieta, 1986) e J. M. Fornell Lombardo (lat.-esp., Anchieta, 1992).

${ }^{11}$ Sobre a obra de Anchieta, v. Fonda (1972) e Anchieta (1988). V. também as primeiras biografias em Caxa; Rodrigues (1988).

12 Maria Aparecida Ribeiro observa junto com José de Alencar que Anchieta nunca fala com voz própria no poema e que o seu personagem fica, portanto, pouco vivo (Ribeiro, 2013, p. 28-29).

13 Desenvolve-se com mais detalhe o teor autorreflexivo do poema em Friedlein (2018).
} 
modalidades da sua autorreflexão, convém primeiro analisar a estrutura narratológica do poema, já que ambas se encontram numa relação de mútua determinação.

Logo a seguir do proêmio épico, o primeiro canto abre uma diegese cujos protagonistas são o jovem religioso Anchieta e os índios moradores nos arredores da aldeia de missão de Piratininga. Cada domingo acodem para reunir-se, fazer oração e escutar o relato evangélico, para eles fascinante, que forma a parte central de cada um de nove cantos, menos o décimo e último, que desempenha função de epílogo. Depois de cada relato intradiegético, o caixilho narrativo é fechado, terminando o canto com uma breve cena de oração e despedida dos índios ou, por vezes, com alguma cena mais elaborada. $\mathrm{O}$ poema é formado, portanto, por nove serões em Piratininga e um epílogo ambientado dez anos mais tarde no Espírito Santo, assim como na hora da morte de Anchieta. No primeiro serão, Anchieta conta o nascimento de Jesus e a visitação dos magos, no segundo a sua infância e tentação no deserto. Nos outros serões seguirão entre outros o Sermão da Montanha, a morte de João Batista, as parábolas predicadas por Jesus, o milagre de Lázaro, a visita de Jesus ao templo, a Última Ceia e a Paixão, seguindo, portanto, o percurso narrativo conhecido dos Evangelhos. Depois da Paixão e Resurreição de Cristo, acaba o canto nono em seco, com um efeito calculado de interrupção abrupta.

A diegese primária, no entanto, começa no primeiro canto quando os índios, e com eles a jovem Nahyda, se dirigem à ermida do missionário. Celebra-se uma missa ao ar livre no domingo a seguir, no segundo canto. Uma semana depois, no terceiro, uma enchente dificulta, mas não impede a reunião dos fiéis. Nos dois cantos seguintes a diegese é dedicada ao anúncio e ao relato de um pesadelo premonitório de Nahyda, em que se anuncia um fratricídio sanguinolento com imagens apocalípticas. Efetivamente, no canto a seguir a aldeia é objeto de um assalto perpetrado por um grupo de índios pagãos. Depois do enterro dos mortos e o serão do missionário, novo assalto causa novas vítimas entre os fiéis. No canto sétimo, Anchieta experiencia, depois de saudosa recordação da sua ilha natal de Tenerife, uma visão da batalha de Alcácer-Kebir, quando um mensageiro da baía de Guanabara noticia a morte de Estácio de Sá em Niterói. Na mesma altura faz-se perceber uma doença de Nahyda. Depois de reunir-se com os chefes no final do canto VII, Anchieta resolve no canto seguinte mandar guerreiros em missão de socorro a Guanabara, e entre eles parte Jadir, o jovem amado de Nahyda. Já entrada na sua agonia, a moça participa do serão em que Anchieta relata a Última Ceia e o início da Paixão de Cristo. Quando Jadir volta da batalha no canto nono, Anchieta já só pode acompanhálo ao túmulo de Nahyda. No último canto, com a colônia já em pleno florecimento, Anchieta por sua vez será acompanhado por Jadir na hora da sua agonia em Espírito Santo. A morte do padre acontece acompanhada por uma visão do grandioso futuro da pátria, na justiça e no império da lei.

No esquema do texto seguinte (quadro 1), as três fases de cada canto correspondem a uma linha da tabela.

\begin{tabular}{|l|l|l|l|}
\hline & \multicolumn{1}{|c|}{ 1 - diegese } & \multicolumn{1}{c|}{ 2 - intradiegese evangélica } & \multicolumn{1}{c|}{ - diegese } \\
\hline I & $\begin{array}{l}\text { Proposição e invocação } \\
\text { - não à Arvore da Ciência } \\
\text { - sim à Arvore da Cruz } \\
\text { - invocação da musa sacra } \\
\text { Diegese } \\
\text { - índios dirigem-se à ermida }\end{array}$ & $\begin{array}{l}\text { Relato de Anchieta (estr. 13-39) } \\
\text { - Gênesis } \\
\text { - os magos abandonam os livros } \\
\text { - nascimento de Jesus, fuga ao Egipto }\end{array}$ & $\begin{array}{l}\text { Diegese } \\
\text { - natureza de manhã } \\
\text { - oração dos fiéis } \\
\text { - Nahyda e o menino } \\
\text { Jesus }\end{array}$ \\
\hline $\begin{array}{l}\text { Digressão: Hino ao domingo } \\
\text { Diegese } \\
\text { - Anchieta lê a Bíblia } \\
\text { - missa ao ar livre e banquete }\end{array}$ & $\begin{array}{l}\text { Relato de Anchieta (estr. 8-14) } \\
\text { - infância e batismo de Jesus } \\
\text { - tentativa de sedução pelo demônio, } \\
\text { cosmovisão e vôo a Jerusalem }\end{array}$ & $\begin{array}{l}\text { Diegese } \\
\text { oração e despedida }\end{array}$ \\
\hline
\end{tabular}




\begin{tabular}{|c|c|c|c|}
\hline III & $\begin{array}{l}\text { Digressão: Hino ao Sol } \\
\text { Diegese } \\
\text { - uma enchente não impede a } \\
\text { reunião dos fiéis }\end{array}$ & $\begin{array}{l}\text { Relato de Anchieta (estr. 5-36) } \\
\text { - milagres e apóstolos } \\
\text { - Sermão da Montanha } \\
\text { Digressão: Hino à beleza da natureza } \\
\text { - Maria Madalena }\end{array}$ & \begin{tabular}{|l|} 
Diegese \\
- oração e despedida
\end{tabular} \\
\hline IV & $\begin{array}{l}\text { Diegese } \\
\text { - Anchieta contempla a } \\
\text { natureza da Terra de Santa } \\
\text { Cruz, porém, sem Deus } \\
\text { - Nahyda anuncia seu sonho } \\
\text { - os fiéis celebram a chegada } \\
\text { de Anchieta }\end{array}$ & $\begin{array}{l}\text { Relato de Anchieta (estr. 3-29) } \\
\text { - Jesus na casa de Maria } \\
\text { - Ave-Maria de Anchieta e troca de } \\
\text { fio narrativo } \\
\text { - dança da filha de Herodias, } \\
\text { morte de João Batista } \\
\text { - Jesus aparece aos apóstolos como } \\
\text { Deus verdadeiro }\end{array}$ & $\begin{array}{l}\text { Diegese } \\
\text { - despedida }\end{array}$ \\
\hline $\mathbf{V}$ & $\begin{array}{l}\text { Digressão: Natureza é } \\
\text { caminho a Deus } \\
\text { Diegese } \\
\text { - três partes do sonho de } \\
\text { Nahyda: aparição do diabo, } \\
\text { Caim no deserto, aldeia } \\
\text { inundada de sangue } \\
\text { - lágrimas de Anchieta } \\
\text { - grandiosa noite americana }\end{array}$ & $\begin{array}{l}\text { Relato de Anchieta (estr. 4-14) } \\
\text { - Jesus caminha sobre as águas } \\
\text { - parábolas (Filho pródigo) }\end{array}$ & \begin{tabular}{|l} 
Diegese \\
- saída do sol, \\
Anchieta retira-se
\end{tabular} \\
\hline VI & $\begin{array}{l}\text { Diegese } \\
\text { - assalto de índios pagãos } \\
\text { - enterro dos heróis mortos }\end{array}$ & $\begin{array}{l}\text { Relato de Anchieta (estr. 3-13) } \\
\text { - Lázaro }\end{array}$ & $\begin{array}{l}\text { Diegese } \\
\text { - chegada de índios } \\
\text { assaltados de novo } \\
\text { - um morto em pose } \\
\text { de oração } \\
\end{array}$ \\
\hline VII & $\begin{array}{l}\text { Diegese } \\
\text { - recordação de Tenerife } \\
\text { - o Anjo da morte } \\
\text { - visão de Alcácer-Kebir } \\
\text { - um mensageiro: ataque dos } \\
\text { tamoios a Niterói, } \\
\text { morte de Estácio de Sá } \\
\text { - doença de Nahyda }\end{array}$ & $\begin{array}{l}\text { Relato de Anchieta (estr. 5-17) } \\
\text { - Jesus no templo } \\
\text { - maldição da figueira }\end{array}$ & $\begin{array}{l}\text { Diegese } \\
\text { - reunião de Anchieta } \\
\text { com os chefes }\end{array}$ \\
\hline VIII & $\begin{array}{l}\text { Diegese } \\
\text { - partida dos guerreiros para } \\
\text { Guanabara } \\
\text { - Nahyda agonizante } \\
\text { participa do serão }\end{array}$ & $\begin{array}{l}\text { Relato de Anchieta (estr. 2-11) } \\
\text { - Judás } \\
\text { Digressão: invocação à musa } \\
\text { - Festa da Páscoa } \\
\text { - Última Ceia } \\
\text { Digressão: invocação a Cristo } \\
\text { - começo da Paixão }\end{array}$ & $\begin{array}{l}\text { Diegese } \\
\text { - morte de Nahyda }\end{array}$ \\
\hline IX & $\begin{array}{l}\text { Diegese } \\
\text { - Jadir volta da batalha } \\
\text { - Jadir com Anchieta ao pé } \\
\text { do túmulo de Nahyda } \\
\end{array}$ & $\begin{array}{l}\text { Relato de Anchieta (estr. 1-20) } \\
\text { - Paixão de Cristo } \\
\text { Digressão: invocação da musa cristã } \\
\text { - Paixão de Cristo e Resurreição }\end{array}$ & -- \\
\hline $\bar{X}$ & $\begin{array}{l}\text { Diegese } \\
\text { - dez anos depois, } \\
\text { florecimento da colônia } \\
\text { - Anchieta em Espírito Santo, } \\
\text { acompanhado por Jadir } \\
\text { - morte de Anchieta, } \\
\text { visão do futuro da pátria }\end{array}$ & -- & -- \\
\hline
\end{tabular}

Quadro 1: Conteúdo e narratologia de Anchieta ou o Evangelho nas selvas

Essa construção narratológica de Varela não teve boa acolhida crítica. Antonio Candido critica a falta de determinação mútua entre os dois níveis narrativos: 
A concepção é defeituosa, não havendo relação necessária entre a matéria central (vida de Jesus) e o pretexto de imaginá-la narrada aos catecúmenos por Anchieta, que aparece no começo e no fim de cada canto, em cenas que servem apenas de tributo ao sentimento nacional. A narrativa poderia desenrolar-se, sem o menor prejuízo, na China ou no Congo. (Candido, 2006, p. 581).

Talvez o mestre não seja totalmente convincente nesse ponto. Os pontos de contato entre o Evangelho, que se quer universal, e o seu contexto narrativo, situado na primeira colonização brasileira, emergem ao segundo olhar. No seu pesadelo premonitório, Nahyda já se mostra atingida pela linguagem bíblica ouvida nos serões quando visualiza o dilúvio de sangue provocado pelo fratricida Caim. Atingida pela doença, morrerá na hora daquele serão em que Anchieta conta a Última Ceia e o começo da paixão de Cristo. Enquanto a Paixão de Cristo traz a Salvação do gênero humano, a morte da vítima Nahyda inaugura o período de florecimento da nova comunidade brasílica. Outra correspondência da diegese com o relato evangélico manifesta-se quando do enterro das vítimas do assalto. que acontece no dia em que Anchieta contará com toda profusão o episódio de Lázaro, ressuscitado do seu túmulo.

\section{A autorreflexividade nas instâncias de fala: Jesus Cristo, Anchieta, o Eu}

A autorreflexividade em Anchieta manifesta-se através de várias instâncias de fala e em modalidades diferentes. Em primeiro lugar, articulam-se a voz do autor e de vários contemporâneos, como o editor E. G. Possolo e um amigo de infância de Varela e jornalista na altura, Ferreira de Menezes, nos diversos paratextos. No entanto o poema carece de alguns outros tipos de paratextos frequentes na poesia épica como, por exemplo, notas autorais de rodapé, marginais ou finais. ${ }^{14}$ Em segundo lugar, no proêmio do poema, assim como em várias digressões no poema, expande-se a voz do Eu, seja chamado de Eu narrativo ou Eu poético. Em outros exemplos de poesia épica essa instância seria chamada de narrador épico, mas evitaremos o termo no caso do poema de Varela, não por inadequado, mas pela única razão de prestar-se à confusão quando se tratará de analisar a quais instâncias de fala do poema são atribuíveis as caraterísticas de narrativo e poético.

Em terceiro lugar, Anchieta assim como os personagens da sua diegese evangélica, com Jesus Cristo no centro, seriam suscetíveis de articular conteúdos autorreflexivos nos seus discursos; porém é mais relevante nesse sentido sua encenação como quem age e fala. Nos trechos a seguir nos ocupará especialmente a questão de saber até que ponto Anchieta é encenado como poeta nos seus atos de fala. Da tríplice distinção de instâncias de fala decorre a questão da interrelação entre elas: autor, Eu poético e personagens diegéticos e intradiegéticos.

Como último nível de manifestação de autorreflexividade há que levar em conta a intertextualidade enquanto referência aos discursos existentes fora do texto, como já se viu no proêmio e na cosmovisão com sua referência à tradição épica.

Desses níveis de manifestação de autorreflexividade, em Anchieta como em tantos outros exemplos de poesia épica marcada pelo Romantismo, o Eu do poema é sem dúvida a instância mais prolífica, ganhando espaços e modalidades de articulação que antes do surgimento da sujetividade romântica eram menos explorados. ${ }^{15}$

Diferenciar entre as instâncias de fala nos leva a constatar, em primeiro lugar, a existência de três momentos temporais, com os seus personagens correspondentes: na

\footnotetext{
${ }^{14}$ Os paratextos, menos relevantes para a autorreflexividade no caso de Anchieta, não serão mais seguidos nesta pesquisa. Em geral, remete-se para essa questão na poesia épica a Marcos Machado Nunes (2020, p. 248-252).

15 Sobre a potencialidades do subjetivismo na poesia épica do século XIX, cf. Brunke, 2019.
} 
intradiegese, Jesus Cristo no momento de sua vida e Paixão; na diegese, José de Anchieta nos tempos da primeira colonização, e na extradiegese, o Eu poético situado no século XIX.

Pelo que diz respeito a Jesus Cristo, os conteúdos autorreflexivos são relativamente escassos e não chegam muito para além do que se esperaria. Jesus em jovem é mostrado como eloquente, revelador de doutrinas, meigo no gesto e doce na fala:

“A doçura / Da palavra eloquente, os gestos meigos [...]” (II, 9)

"Movidas [as gentes] / Pela eloquente voz, pelas doutrinas / Desse inspirado e ríspido mancebo, / E mais ainda pelo santo exemplo / Do santo proceder [...]" (II, 11)

"A fama de seu nome, e das doutrinas / Santas e luminosas que professa, / Das sublimes acções, e da doçura / Do trato, das palavras, vôa, passa / Além das cordilheiras" (III, 11)

Jesus adulto é mostrado no seu impulso contra o saber hipócrita dos fariseus, assim como na simplicidade das suas parábolas:

"[...] parabolas singelas / Que resumem a lucida doutrina / Simples, mas palpitantes de verdade" $(\mathrm{V}, 12)$

"As formosas parabolas, ungidas / Da mais suave e doce poesia, / Os singelos paineis, onde a verdade, / Simples como a expressão da natureza, / Os mais rudes espiritos cativa, / A linguagem concisa, porém bella / Do divino pastor, melhor ensinam / Do que das Synagogas orgulhosas / As extensas lições, e os vãos discursos” (V, 14)

Como não pode surpreender, forma-se em primeiro lugar o ideal da formosura na simplicidade do discurso de Jesus, que é transmissor de doutrinas e verdades sem o academicismo das instituições do saber do seu tempo.

O que se diz aqui em louvor da simplicidade na poesia, atinge a poetologia do texto em geral e converte-se em ideal do Eu poético? Alfredo Bosi responderia pela negativa:

Embora não seja difícil colher exemplos felizes de notação do mundo agreste [no Anchieta de Fagundes Varela], o tom edificante do conjunto acaba toldando a solene pureza da mensagem evangélica, que se desfigura quando tocada pela retórica. Mesmo que esta venha de uma alma emotivamente religiosa como a de Fagundes Varela. (Bosi, 1985, p. 131-132).

Segundo o crítico, Varela não se apropriaria do ideal discursivo da simplicidade de Cristo, mas a transformaria com irritantes doses de retórica. Uma verdadeira comprovação requereria análises estilísticas que estão fora do alcance deste artigo. Mas o Eu poético e o Jesus Cristo do relato de Anchieta compartilham, sem dúvida, o seu ímpeto anti-acadêmico e antilivresco.

Mais determinante para o teor autorreflexivo do poema será a personagem de Anchieta. Em primeiro lugar, o Eu do poema parece exaltar o Anchieta poeta mencionando o Poema marianum:

"Alma inspirada de Anchieta illustre, / Espirito do apostolo das selvas! / Sabio e cantor, luzeiro do futuro! / Tu, que [...] traçaste os versos / Do poema da Virgem, e ensinaste / Aos povos do deserto a lei sublime / [...] Ensina á minha musa timorata / A 
linguagem celeste que fallavas / Dá-lhe a doce expressão, a graça infinda, / A força, a eloquencia e a verdade / D'essas singelas narrações que á noite / Fazias nos outeiros, nas florestas, / Ás multidões que ouvindo-te choravam, / e pediam as aguas do baptismo" (I, 10).

Observando esse trecho cautelosamente, nota-se que o Eu não invoca Anchieta, pedindo para ele uma voz poética como a do Poema marianum. Antes ele aspira a saber imitar as caraterísticas d'essas singelas narrações que fazias nos outeiros - ou seja, não aspira a imitar ou a seguir a língua poética do Anchieta poeta, mas a plasmar em poesia a língua oral de um Anchieta visto como predicador e narrador.

Com essa observação concordam vários outros fatos. Para começar, Anchieta é continuamente chamado de "narrador". Nos seus serões ele próprio usa o verbo contar quando se dirige ao seu público neófito: "Tentações de Satan, - deveis lembrar-vos, / Irmãos, repete o narrador, - contei-vos, / No passado serão; direi agora [...]" (III,5); ou bem: "E o santo narrador assim lhes falla: [...] Eu acabava, irmãos, de relatar-vos / O milagroso caso [...]" (IV, 3).

Fora dos seus serões com os índios, Anchieta é mostrado duas vezes folheando a Bíblia (III, 4; IX, 1), mas nunca no trabalho intelectual necessário para redação dos textos que o Anchieta histórico de fato escreveu. Assim, o Anchieta de Varela escolhe no seu primeiro serão a opção de relatar com toda a profusão a história dos três magos, apresentados como astrólogos dedicados à sua ciência da natureza que abandonam, levados embora pela música celeste que os faz seguir a estrela. No fim desse primeiro serão, Nahyda encanta-se pelo menino Jesus, e Anchieta comenta essa compreensão ingênua: "os sabios todos / Si assim pensassem quando os livros volvem, / E buscam monumentos no passado, / E perdem-se em audazes conjecturas, / Mais felizes seriam!” (I, 42). ${ }^{16}$ Digno de remarcar é que a imagem antilivresca do missionário desenhada aqui refere-se a um autor histórico que redatou, entre outros, uma gramática do tupi. A biografística do padre vai por um caminho totalmente diferente, quando costuma representar o padre como um grande erudito, mesmo nas precárias condições da missão, e lhe atribui o título de "segundo Adão", por conta do saber que equipararia o missionário ao patriarca bíblico que deu os nomes às coisas. Inclusive a aldeia de Piratininga acostuma ser representada como "colégio" onde se desenvolveriam grandes práticas de erudição: pesquisa, leitura, escrita e representação dramática, além da prática do canto, tanto de Anchieta como dos seus discípulos. ${ }^{17} \mathrm{O}$ Anchieta de Varela não é mostrado envolvido em nenhuma dessas atividades, e praticamente não aparece como poeta no poema. A sua faceta lírica, embora não totalmente calada, fica claramente marginalizada. Finalmente, comparando com a profusão de milagres e ações benéficas anchietanas que relatam as biografias, no poema de Varela, onde não acontecem milagres, Anchieta é relativamente pouco mostrado praticando a imitatio Christi nas suas ações. Em vistas de tantas ausências, forçosamente há-se de chegar à conclusão de que o Anchieta de Fagundes Varela é sobretudo uma outra coisa: ele é o narrador de Cristo.

Essa caraterística se manifesta de maneira especialmente ilustrativa num momento do texto em que Anchieta interrompe seu relato evangélico na dúvida de como continuar. Lança um pedido de inspiração que em princípio poderia ser próprio de um poeta:

\footnotetext{
$16 \mathrm{O}$ mesmo impulso anti-intelectual constata-se numa cena de encanto natural: "Quem se despir da frivola sciencia / Das vaidosas escolas das cidades, / E, filho amante, repousar a fronte / No regaço feliz da natureza $[\ldots]$ ' (III, 34).

${ }^{17}$ Vale como exemplo mais representativo da biografística anchietana a vida escrita por Simão de Vasconcelos que descreve essas práticas (Vasconcelos, 1672, liv. I,5, p. 26-27), sem mencionar, no entanto, serões como os do Anchieta de Varela. O dom da eloquência, ao invés, é atribuído ao discípulo Gaspar Lourenço, "rio de eloquencia Brasílica" (ib., liv. I,8, p. 44), e a realização de reuniões com os índios, ao discípulo Gregório Serrão (ib., p. 43).
}

Rev. Bras. Lit. Comp. Niterói, v. 22, n. 40, pp. 25-39, mai. /ago. 2020

https://doi.org/10.1590/2596-304X20202240rf 
"Cala-se o narrador. Alguns momentos / Conserva-se, indeciso e pensativo / Como buscando um fio, que approxime / Dois afastados, differentes factos. / O penoso labor do entendimento / Nas austeras feições se manifesta. / - Espirito dos tempos que passaram! [...] Inspira minha voz, minh'alma inspira!"' (IV,10)

Mas na sequência sua hesitação revela-se ter sido de quem conta uma história e não de quem busca inspiração poética. A solução que Anchieta acha para prosseguir o seu relato será, portanto, prosaica e consiste, simplesmente, em mudar de tema:

\section{"Deixemos o Senhor [...] Voltamos ao Baptista o pensamento" (IV, 10).}

Apesar do uso do verbo inspirar, não se trata, pois, de um poeta invocando uma instância de inspiração num momento de desafio poético, mas de um narrador perdido entre os fios do seu relato. ${ }^{18}$

Vale dizer ainda que o mesmo passo prova como o Anchieta narrador relata os acontecimentos evangélicos com palavras e estilo próprios dele; não recita o texto evangélico, mas o conta ao seu público, usando o seu talento de narrador. Esse seu relato, porém, não manifesta concessões ao auditório indígena, como poderia ser, por exemplo, a inserção de explicações devidas à distância cultural que separa o mundo evangélico do mundo americano. Essa ausência pode ser lida, mais uma vez, como indício da universalidade reclamada pela mensagem evangélica. Visto desde a perspetiva narratológica, a falta de concessões ao público nos lembra, por outro lado, que as falas de Anchieta, por mais que estejam articuladas em discurso direto, não deixam de ser ao mesmo tempo enunciações do Eu poético. Dito de maneira rasa: o Anchieta da ficção não se dirigia ao seu público com os versos que nós lemos. $\mathrm{O}$ Eu poético do texto unifica estilísticamente os trechos de Anchieta com os seus próprios. Mesmo assim, que as instâncias do narrador e do poeta não deixam de ser instâncias superpostas, mas sempre separáveis, o próprio texto se encarrega de salientar:

"[o missionário] As gentes abençoa, e então começa / Da Redempção a historia sacrosanta, / Que a musa do poeta ornou de flôres, / Tristes flôres sem viço e sem perfumes" (I, 11).

Essa constatação leva a observar o Eu poético de mais perto. Se Anchieta é mostrado como narrador e, por outro lado, o caráter poético do poema fica fora de dúvida, esse caráter só pode ser devido ao Eu. As caraterísticas que esta voz possui serão especificadas a seguir.

1) Em primeiro lugar, a voz que enuncia esse poema narrativo apresenta-se como voz poética, e não de narrador. Usa por conseguinte os recursos imagéticos da poetologia tradicional: entre elas, contam-se as invocações e pedidos de inspiração, ou a metáfora recorrente da musa para designar a produção do próprio trabalho, que se encontra dezessete vezes ao longo do poema, em fórmulas como "Ensina á minha musa timorata / A linguagem celeste" $(\mathrm{I}, 10)$, apóstrofes como "Tu soluças? / Tu escondes o rosto, ingenua musa? / Oh! continúa e chora" (IX,9), e a exclamação "Musa, silencio!" (VI,4). Os paratextos confirmam e ressaltam a poeticidade do texto com a designação de 'cantos' para as suas partes.

2) A adjetivação escolhida pelo Eu para sua obra e para ele próprio denota a humildade, devida ao contexto do poema sacro: "Não; não entoarei meus pobres hymnos / À Sombra tua [da Árvore da Ciência] que Satan protege" $(\mathrm{I}, 6)$ ou, dirigindo-se à Cruz: "Permitte que o mais rude entre os cantores, / O mais rasteiro sêr que te ha beijado" (I,2). Contudo, o Eu não abre

\footnotetext{
${ }^{18}$ V. no mesmo sentido a Ave Maria proferida pela voz do narrador na hora de Jesus voltar para casa da sua mãe (IV,9), e que não possui forma de poema inserido no discurso narrativo, mas é convertido em discurso narrado: Anchieta não canta essa Ave Maria, e sim a conta.
} 
mão da esperança de permanência dos seus versos mais além da própria morte: "Oh! não! não morrereis, meus pobres cantos! / Não passarás nas trevas, deslembrada, / Musa christã... Passarás ao porvir, oh! casta Musa!” $(\mathrm{I}, 12)$.

3) Além desses motivos pouco surpreendentes num poema sacro, o Eu se apresenta, de maneira mais específica, como uma voz explícitamente anti-erudita, anti-académica, $e$ antilivresca, como seria próprio do discurso místico. As três estâncias proemiais do poema estão dedicadas a declarar um 'não' veemente à 'Árvore da Ciência' e um 'sim' sentido à 'Árvore da Cruz'. Essa caraterística que já foi constatada na figura de Jesus Cristo como na de Anchieta, é efetivamente compartilhada por todas as instâncias de fala. Se Anchieta elogia a compreensão ingênua de Nahyda e condena o saber infeliz dos livros, o Eu poético toca na mesma corda, fulminando livros e história a favor dos seus versos simples: "Homens que lêdes estes rudes cantos, / Viandantes de um valle de infortunios, [...] Não busqueis nas lições das grandes sabios, / Nem nos padrões da historia, a luz brilhante / Que desvenda os mysterios de além mundo!" $(\mathrm{X}, 4)$.

4) Se o discurso do Eu não pode ser inspirado nos livros, apresenta duas fontes de inspiração alternativas. Em primeiro lugar, o seu poema recrea uma lembrança infantil do Eu. Propõe-se a relatar "As maravilhas que aprendeu, creança, / Dos santos labios de ministro santo" $(\mathrm{I}, 2)$ e, portanto, uma experiência individual que será relembrada sob os auspícios da 'musa cristã' (IX,11).

5) A segunda fonte de inspiração será a natureza do Brasil, evocada como "Musa da creação" $(\mathrm{V}, 1)$ com tonalidade hínica em várias digressões ao longo do poema. Ora, se em poemas como a A confederação dos tamoios o contato privilegiado com a natureza como fonte de inspiração é reservado aos cantores índios, em Anchieta é o Eu que a invoca e se inspira nela.

6) As invocações e explícitas reflexões poetológicas feitas no poema merecem uma análise atenta, já que a sua atribuição às instâncias de fala não é sempre óbvia e, porém, crucial para a nossa análise. No conjunto, parece argumentável que os trechos explícitamente poetológicos assim como as invocações à musa poética são todos atribuíveis ao Eu poético, e nunca ao Anchieta narrador. Como exemplo mais claro, vejamos o momento em que se trata de relatar a traição de Judas. Anchieta narrador, afetado pela gravidade do assunto, pausa por um instante. Segue a invocação a uma musa ainda desconhecida para descrever os inauditos fatos. Ora, essa invocação é atribuída não a Anchieta narrador, mas a uma instância diferente dele que ocupa a segunda metade da citação - é o Eu poeta sob forma de sua "musa': "Aqui tristonho, / Aqui turbado, o narrador calou-se: / Aqui também suspiras e emmudeces, / Pobre, singela musa!" (VII,2; grifo meu). ${ }^{19}$

Considerando essas caraterísticas em conjunto, fica evidente como o Eu do texto se encena como poeta e, portanto, diferenciado do narrador Anchieta. Por conseguinte, as três instâncias de fala do poema nos seus três momentos temporais possuem, cada uma, seu respetivo ato de fala dominante: Jesus predica, Anchieta narra, e o Eu canta poeticamente: Jesus Cristo possui a simplicidade nas suas parábolas e sermões, Anchieta a magia da sua narração, e o Eu a inspiração da poesia.

Diferente de outros poemas sacros, essa triplicidade narratológica não apresenta indícios forçosos para ser lida como uma fileira messiánica, ao modo que se vem afirmando na exegese de Dante para as figuras de Virgílio, Jesus e Dante. Nem o Anchieta de Fagundes Varela é mostrado como uma figura messiânica, ${ }^{20}$ nem o Eu, e por extensão Fagundes Varela, aspira a

\footnotetext{
${ }^{19}$ Os outros casos: a invocação dirigida a Cristo há-de ser atribuída ao Eu poético esgotado, já que também é a voz dele que fecha a estância anterior (VIII,7). - De mais duvidosa atribuição é a invocação que acontece no meio da Paixão. O fato de ocupar uma estância inteira, separada do que vem antes e depois, faz possível atribuíla ao Eu poético, como acontece no resto do poema quando é questão de poesia (IX,11).

${ }^{20}$ Maria Aparecida Ribeiro concorda em entender o Anchieta do poema em primeiro lugar como santo e apóstolo, não como poeta, mas vê algum indício de ele ser representado como figura Christi (Ribeiro, 2013). No
} 
ser um novo Anchieta no sentido de um seguimento histórico ou tipologia bíblica. As três instâncias de fala circumscrevem-se cada uma ao seu mundo sem formarem juntas uma história, nem da salvação nem poetológica.

\section{Conclusão}

Vendo a A confederação dos tamoios e o Anchieta lado ao lado, manifesta-se agora uma clara diferença nos conceitos chave das suas poetologias. Se os dois poemas pertencem ao indianismo romântico e visam a uma valoração positiva dos tempos do primeiro colonialismo, Gonçalves de Magalhães foca na sua epopeia heroica o aspecto combativo do encontro, enquanto Varela encena uma Idade de Ouro do Brasil (X,3), inaugurada pelo missão cristã no meio de uma natureza ainda intocada, e atribui-lhe uma simplicidade primordial. Mas, ao contrário de Gonçalves de Magalhães, a Idade de Ouro brasílica de Varela não aloja o berço da poesia. Enquanto em A Confederação dos Tamoios os índios pagãos, os índios neófitos, os portugueses e mais do que todos José de Anchieta fazem poesia, cantam ou dançam, e até os execrados franceses têm suas canções, nada disso acontece no Anchieta de Varela. Os seus índios, sejam já cristianizados ou ainda "selvagens", nunca são mostrados exercendo nem a sua tradição cultural própria, nem a novamente aquirida. Sua vida cultural resume-se na constatação de que abandonaram a sua tradição e passaram a entoar unicamente cantos cristãos. ${ }^{21}$ Mas de qualquer maneira a encenação da vida cultural e artística de Piratininga está fora do foco de Fagundes Varela. No seu poema, a poesia reside exclusivamente no Eu do poeta.

Gonçalves de Magalhães visa estabelecer uma tradição da poesia nacional, arrancando desde o poeta Anchieta, e nela aspira a ocupar o seu lugar. A poesia para ele é um fenômeno coletivo e histórico, com as suas orígens nas artes naturais do índio, depois o seu momento de definição na vinda de Anchieta e com ele, do Cristianismo, e ainda, na continuação dessa linha de poesia nacional por aqueles contemporâneos que optam por temas e estilos autóctones, entre os quais o próprio Gonçalves de Magalhães.

Para Fagundes Varela, a poesia carece dessa dimensão histórica. Poesia dá-se isoladamente dentro do Eu, e no momento contemporâneo, sem aportação nem dos índios nem dos poetas nacionais na esteira de Anchieta e, mirando bem, até sem colaboração daqueles poetas sacros mencionados no poema, já que eles não são modelos a ser imitados. São predecessores na mesma missão, mas sem aportar a poética que a obra de Varela há-de seguir. A poesia é percebida então como criação individual e instantânea, e não coletiva e histórica. Fagundes Varela abandona o pensamento historicista e individualiza o ato poético, e do seu poema pode-se afirmar que passa da autorreflexividade histórica a uma autorreflexividade "presencista". O casamento da natureza brasileira com o cristianismo que dá como fruto a poesia brasileira e acontece em Gonçalves de Magalhães no tempo histórico de Anchieta, em Fagundes Varela, por sua vez, acontece na pessoa dele próprio ou, talvez mais exatamente, no seu texto. Os seus dois níveis narratológicos significam o encontro da natureza brasileira, diegética, e o Evangelho, intradiegético. Fagundes Varela busca a poetização desse encontro de natureza e Evangelho como um momento em que se deu uma compenetração ingênua. Ele elabora a poetização desse momento, mas não em prol da nação e a sua história, mas como contributo para a poesia sacra universal, como poderia acontecer - em palavras do mestre - no Congo ou na China.

entanto, Varela não mostra Anchieta nem produzindo milagres, nem rodeado por doze discípulos, como a biografística anchietana o faz.

21 “[...] as moças cantam / Não as lendas das tabas bellicosas / Mas da Musa Christã saudosos hymnos” (II,7).

Rev. Bras. Lit. Comp. Niterói, v. 22, n. 40, pp. 25-39, mai. /ago. 2020

https://doi.org/10.1590/2596-304X20202240rf 


\section{REFERÊNCIAS}

ANCHIETA, José de. De gestis Mendi de Saa: edição fac-similar. Apresentação Eduardo Portella. Introdução Paulo Roberto Pereira. Rio de Janeiro: Fundação Biblioteca Nacional, 1997.

ANCHIETA, José de. De gestis Mendi de Saa: poema épico. Introd., versão e notas de Armando Cardoso. São Paulo: Loyola, 1986. (Obras completas de José de Anchieta, v.1).

ANCHIETA, José de. Vida y obra. Ed. Francisco González Luis et al. La Laguna [Tenerife]: Ayuntamiento, 1988.

ANCHIETA, Joseph de. De gestis Mendi de Saa, ed. José María Fornell Lombardo. Granada: Compañía de Jesús, 1992.

ARIAS-SCHREIBER BARBA, Felix. Das erste Epos aus Amerika und die Aeneis Vergils: Der Aufbau von Anchietas De gestis Mendi de Saa und die klassische Epik. Hamburg: Diplomica, 2011.

AZEVEDO, Vicente de Paulo Vicente de. A vida atormentada de Fagundes Varela, São Paulo: Martins, 1966.

BARROS, Frederico Ozanam Pessoa de. Poesia e vida de Fagundes Varela, São Paulo: Edameris, 1965.

BOSI, Alfredo. História concisa da literatura brasileira. São Paulo: Cultrix, 1985.

BRIESEMEISTER, Dietrich. “José de Anchietas 'De gestis Mendis de Saa' (1563)”. In: GROßE, Sybille, and e SCHÖNBERGER, Axel, orgs. Ex oriente lux: Festschrift für Eberhard Gärtner zu seinem 60. Geburtstag. Frankfurt am Main: Valentia, 2002. p. 545-565.

BRUNKE, Dirk. Das romantische Epos am Río de la Plata. Subjektivität und Lyrisierung, Stuttgart: Steiner, 2018.

BRUNKE, Dirk, and FRIEDLEIN, Roger, orgs.. El yo en la epopeya. Nuevos espacios de subjetividad en la poesía épica ibérica y latinoamericana del siglo XIX. Madrid: Iberoamericana, 2020.

CANDIDO, Antonio. Formação da Literatura Brasileira. Momentos decisivos, 1750-1880. Rio de Janeiro: Academia Brasileira das Letras, 2006.

CAXA, Quirício, and RODRIGUES, Pero. Primeiras biografias de José de Anchieta. Ed. Hélio Abranches Viotti. São Paulo: Loyola, 1988 (Obras completas de José de Anchieta; 13).

FONDA, Enio Aloisio. “José de Anchieta, poeta novi-latino”. Revista de Letras, v. 14, 1972, p. $133-152$.

FRIEDLEIN, Roger. "A autorreflexividade na epopeia indianista romântica: Gonçalves Dias, Gonçalves de Magalhães, Daniel Campos”. Brasil/Brazil, v. 31, n. 58, 2018, p. 1-16. 
FRIEDLEIN, Roger. "Encenações cosmográficas. A epopeia renascentista, espaço autorreflexivo (Camões, Corte-Real)”. Veredas, v. 23, 2015, p. 111-126, http://homepage.ruhr-uni-bochum.de/roger.friedlein/download/Friedlein_ Autorreflexividade\%20Camoes\%20Corte-Real\%20in\%20Veredas.pdf.

FRIEDLEIN, Roger, and NUNES, Marcos Machado, and ZILBERMAN, Regina, orgs.. A epopéia em questão. Debates sobre a poesia épica no século XIX. Rio de Janeiro: Makunaima 2020.

HABERLY, David T. "The Mystery of the Bailliff's List: Or, What Fagundes Varela Read". Luso-Brazilian Review, v. 42, n. 2, 1987, p. 1-13.

JAECKEL, Volker. Von Alterität, Anthropophagie und Missionierung. Der Einfluss der Jesuiten auf die kulturelle Identität Brasiliens in der Kolonialzeit (1549-1711). Stuttgart: Ibidem, 2007.

LESTRINGANT, Frank. "Les débuts de la poésie néo-latine au Brésil: le 'De rebus gestis Mendi de Saa' (1563)”. In: LESTRINGANT, Frank, org. L'expérience huguenote au Nouveau Monde: XVI siècle. Genève: Droz, 1996, p. 231-245.

LIMA, Israel Souza. Biobibliografia dos patronos: Fagundes Varela e França Júnior. Rio de Janeiro: Academia Brasileira de Letras, 2003.

MONTEIRO, João. “Anchieta na poesia e nas lendas brasileiras”. In: III Centenario do veneravel Joseph de Anchieta: conferencias preparatorias feitas por occasião do centenario do veneravel Padre Joseph de Anchieta. Lisboa, Paris: Aillaud, 1900, p. 205-246.

NUNES, Marcos Machado. "Perspectiva universalista e epopeia humanitária em paratextos do século XIX português (Tomás Ribeiro e Teófilo Braga)". In: FRIEDLEIN, Roger, and NUNES, Marcos Machado, and ZILBERMAN, Regina, orgs. . A epopeia em questão. Debates sobre a poesia épica no século XIX. Rio de Janeiro: Makunaima, 2020. p. 248-284.

RIBEIRO, Maria Aparecida. “Anchieta no Brasil: que memória?”. História Revista, v. 8, n. 1/2, jan./dez. 2003, p. 21-56.

SILVA, Anazildo Vasconcelos da; RAMALHO, Christina. História da epopéia brasileira. Teoria, crítica, percurso I. Rio de Janeiro: Garamond, 2007.

VARELA, Luís Nicolau Fagundes. “Anchieta ou o Evangelho nas selvas”. In: __. Poesias completas de Fagundes Varela. Rio de Janeiro: Estado da Guanabara, 1970. v. 3.

VARELA, Fagundes [Luís Nicolau]. Anchieta ou O Evangelho nas selvas. Pref. Murilo Araújo. Rio de Janeiro: Zelio Valverde, 1939.

VARELA, L. N. Fagundes “Anchieta ou o Evangelho nas selvas”. In: Obras completas de L. N. Fagundes Varella. Ed. José Alves Visconti Coaracy e Franklin Távora. Rio de Janeiro: Garnier, 1886. v. 3.

VARELLA, L. N. Fagundes. Anchieta ou O Evangelho nas Selvas. Pref. José Ferreira de Menezes. Rio de Janeiro: Imperial, 1875. 
VASCONCELOS, Simão de. Vida do venerável Padre Joseph de Anchieta, Lisboa: João da Costa, 1672.

Roger Friedlein - Doutor em Filologia Românica pela Universidade de Berlim, é professor titular no Romanisches Seminar, Ruhr-Universität Bochum. É autor de Das Streitgedicht im Mitteralter (2019), El yo en la epopeya. Nuevos espacios de subjetividad en la poesía épica ibérica y latinoamericana del siglo XIX (2019), Das romanitische Epos am Río de la Plata (2018) e de Kosmovisionen. Inszenierungen von Wissen und Dichtung im Epos der Renaissance in Frankreich, Portugal und Spanien (2014), entre outras publicações. Coordena o projeto Discurso da épica nas culturas lusófonas do século XIX - Probral Capes/DAAD 2018-2021. Orcid 0000-0001-8844-1721.

Submetido em 02/02/2020

Aceito em 26/03/2020 